\title{
An Overview on Coconut Water: As A Multipurpose Nutrition
}

\author{
Shamal N.Tuyekar ${ }^{1 *}$, Bharvi S.Tawade ${ }^{1 *}$, Kajalkumari S. Singh ${ }^{1}$, Vidula S. Wagh ${ }^{1}$, Prasad K. Vidhate ${ }^{1}$, Rupali P.Yevale ${ }^{2}$, \\ Shweta Gaikwad², Mohan Kale ${ }^{3}$ \\ ${ }^{1}$ UG-Student, Konkan Gyanpeeth Rahul Dharkar College of Pharmacy and Research Institute, Karjat, Dist: Raigad \\ (Maharashtra) 410201, India. \\ ${ }^{2}$ Assistant professor, Department of Pharmaceutical Chemistry, Konkan Gyanpeeth Rahul Dharkar College of Pharmacy and \\ Research Institute, Karjat, Dist: Raigad (Maharashtra) 410201, India. \\ ${ }^{3}$ Principal, Konkan Gyanpeeth Rahul Dharkar College of Pharmacy and Research Institute, Karjat, Dist: Raigad (Maharashtra) \\ 410201, India.
}

*Corresponding authors E-mail: shamaltuyekar27@gmail.com, bharvitawde@gmail.com

Received: 10-04-2021; Revised: 25-05-2021; Accepted: 30-05-2021; Published on: 15-06-2021.

\begin{abstract}
Coconut water and coconut are two natural thirst-quenching foods that are commonly available in most countries. Both the water and the meat of the tender coconut stimulate the body by releasing nutrients. In recent years, researchers have been interested in the health and medicinal benefits of tender coconut products. Sugars, proteins, free amino acids, vitamins, minerals, and growthpromoting factors are among the biologically essential elements contained in it. Since, current research on coconut water is mainly focused on its properties, uses, and nutritional benefits, this review will concentrate on the human health aspect. It describes original properties and applications, which vary from the most simple to the most complex. It also describes its biochemical structure, which is affected by the stage of maturity and hence the variety. The purpose of this review was to learn about the most widely recorded components of coconut water, as well as other research towards their impact on animals and human body. Coconut water contains bunch of nutrition such as vitamins, minerals, amino acids, and phyto-hormones. The recent discovery of coconut water on the medicinal properties shows its real potential for improving human health. The possible anti-cancer properties of particular cytokinin could open up new and exciting avenues for finding cures for various cancers. It's a gift from nature to provide the best remedy for thirst and better health. Because of the antioxidant and anti-cancer properties of different ingredients, it is a more sensible option for removing the poisoning effect of other food that is a part of modern life. Understanding the functions and properties of the individual components of coconut water requires further study, but it will enable us to properly exploit this wonderful and multipurpose liquid with unique biological properties.
\end{abstract}

Keywords: Coconut water, Antioxidant, Nutritional Support, Thirst-quincher, Electrolyte, Medicinal property.

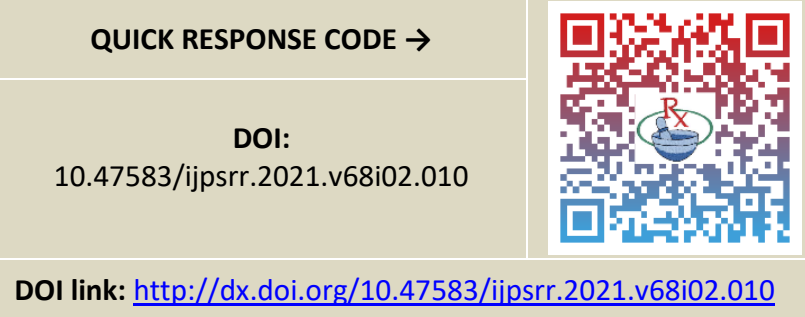

\section{INTRODUCTION}

C oconut water, the transparent liquid found inside young of coconuts, is highly valued for its organic process and medicinal properties. It's been successfully used for oral rehydration, treatment of childhood symptoms, intestinal flu, and cholera in many parts of the world ${ }^{1}$. Since it deteriorates rapidly when exposed to sunlight, this drink is widely consumed as a contemporary in tropical areas. Thermally processed mistreatment ultra-high temperature (UHT) technology is used commercially ${ }^{2}$. However, when coconut water is heated, it loses some of its delicate existing taste as well as some of its nutrients. A non-thermal approach is fascinating for preserving the fresh taste and nutrient content of coconut water, which could improve the marketability and accessibility of this nutritious drink to consumers all over the world. Because of its balanced electrolytes like sodium and minerals that help restore electrolyte losses via skin and urinary pathways, it's been identified as isotonic beverages in nursing ${ }^{3}$. Coconut water has been invited as a natural competitor in the sports drink industry, owing to its delicate scent, taste, and nutritional qualities, as well as the functional qualities needed in an extremely sports drink (Food and Agricultural Organization [FAO]) ${ }^{2}$. Coconut water is primarily composed of water (94\%) and sugars (aldohexose, fructose, and disaccharide) (5\%), proteins $(0.02 \%)$, and lipids $(0.01 \%){ }^{4}$. Minerals, calcium, metal, and manganese are abundant, but the metallic element is scarcely present ${ }^{5,6}$. Because of its low shelf life, the majority of coconut water is consumed recently in tropical coastal areas. It deteriorates and loses much of its sensory and organic process characteristics when exposed to air ${ }^{7}$. Commercially, drink is primarily produced in Indonesia, Philippines, and Thailand by using ultra-high temperature (UHT) sterilization, but many of the nutrients and delicate flavor of coconut water are lost 
during this thermal phase, limiting the product's marketability ${ }^{8,9}$. Coconut water is consumed as a drink in the republic of India, and coconut oil is used as an oil only in Kerala, some regions of Tamilnadu and north Indian states. However, worldwide market of healthcare, skincare, baby oil, and cosmetic sectors mainly on coconut oil and pure coconut oil ${ }^{10,11}$. Coconut water is much more successful than plain water or fruit crush in alleviating symptoms associated with diseases conditions. Coconut water has been used widely as a treatment for infectious disease, dysentery, influenza, and other infectious diseases that cause dehydration over the last 20 years ${ }^{12}$. Thousands of lives have been saved by coconut water, especially in developing countries. Normal water is ineffective in treating extreme dehydration caused by vomiting and symptom, but due to the chemical composition have electrolytic balance in coconut water, it can rehydrate the body and give it the strength and energy it needs to battle the infection.

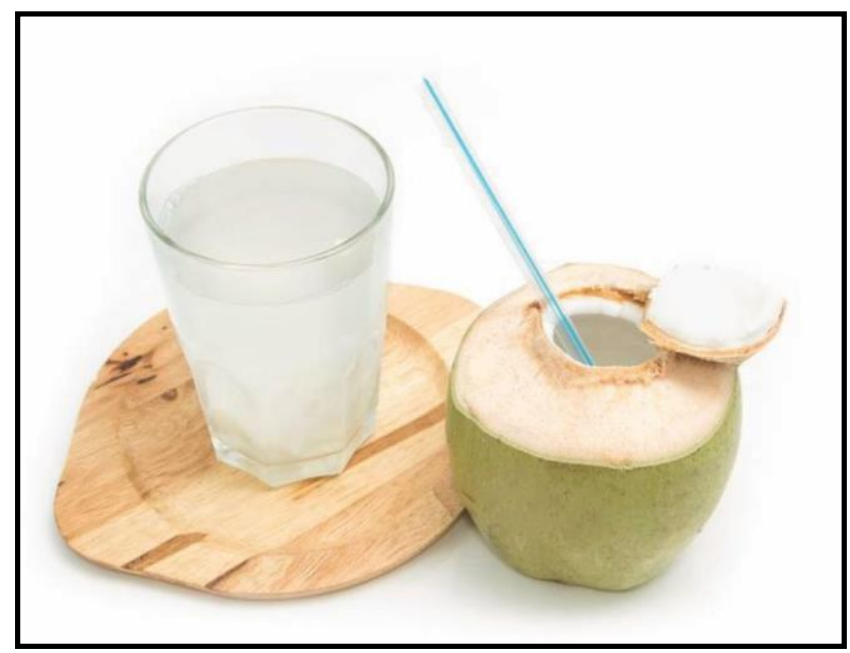

Figure 1: Diagram of Tender Coconut Water (TCW)

\section{Coconut Water - Composition and Characteristics}

Coconut water is a healthy, fat-free beverage of wheat is low in sugars and calories and high in nutrition. Once a coconut is opened, the water starts slowly dropping its nutrients and flavours. This is partially due to enzymes contained in coconut water called peroxidase (POD) and polyphenol (PPO) that interfere with oxygen, causing nutritional and flavour losses ${ }^{13}$. Young coconut water contains more sugar and total phenolic than mature coconut water. Coconut water is sterile in its envelop and contains both organic and inorganic compounds that support the antioxidant system of the human body ${ }^{14}$. Inorganic ions are essential for normal cellular function including enzymatic activation, bone formation, haemoglobin function, gene expression; amino acid, lipid, and carbohydrate metabolism ${ }^{15}$. Coconut water contains several inorganic ions, which add to the coconut water's therapeutic benefit. Coconut's basic ion composition will replenish electrolytes such as sodium, potassium, magnesium, and calcium that are lost via sweat. It can be used as a rehydration drink because the electrolytes in coconut water provide an osmotic pressure that is close to that found in the body without disrupting homeostasis. Tender coconut water (TCW) contains $95.5 \%$ water, $4 \%$ fats, 0.1 percent fat, $0.02 \%$ calcium, $0.01 \%$ phosphorus, $0.5 \%$ iron, a substantial amount of amino acids, mineral salts, vitamin B complex, vitamin, cytokines ${ }^{16}$, and other sugars, alcoholic sugars, lipids, amino acids, nitrogenous compounds, organic acids, and enzymes ${ }^{17}$. Delta-lactones added to the distinctive taste of tender. Tender coconut water protein rich of amino acids such as arginine, alanine, cysteine, and serine than cow's milk protein ${ }^{18}$. Out of all the main minerals presents, potassium plays a significant role in the flavour of tender coconut water. It's worth noting that after four months of exclusive breastfeeding, the amount of calcium in the colostrum steadily decreases. As a result, nursing mothers who drink coconut water regularly will help their babies meet their calcium needs. Tender coconut water contains both ascorbic acid and vitamin B complex, with ascorbic acid concentrations ranging from 2.2 to $3.7 \%$ per $100 \mathrm{ml}$. Ascorbic acid concentrations steadily decrease as the kernel surrounding the water hardens. Folate and vitamin B9 are also present in coconut water. It was discovered in the late 1930 s as a nutrient essential for reducing anaemia in pregnancy and preventing mitochondrial toxicity caused by methanol metabolites ${ }^{19}$. Coconut water is a natural isotonic liquid because of its mineral composition and low total sugar content. Its properties make it a perfect rehydrating and soothing drink after physical activity ${ }^{20}$.

Table 1: Nutrients composition of Mature Coconut water and Tender Coconut water

\begin{tabular}{|c|c|c|}
\hline Composition & $\begin{array}{c}\text { Mature coconut } \\
\text { water }\end{array}$ & $\begin{array}{c}\text { Tender coconut } \\
\text { water }\end{array}$ \\
\hline Total solids \% & 5.4 & 6.5 \\
\hline Reducing sugars & 0.2 & 4.4 \\
\hline Minerals & 0.5 & 0.6 \\
\hline Protein & 0.1 & 0.01 \\
\hline Fat\% & 0.1 & 0.01 \\
\hline Acidity mg \% & 60.0 & 120.0 \\
\hline pH\% & 5.2 & 4.5 \\
\hline Potassium mg\% & 247.0 & 290.0 \\
\hline Sodium mg\% & 48.0 & 42.0 \\
\hline Calcium mg\% & 40.0 & 44.0 \\
\hline Magnesium & 15.0 & 10.0 \\
\hline mg\% & & 106.0 \\
\hline Iron mg\% & 79.0 & 26.0 \\
\hline Copper mg\% & 26.0 & 9.2 \\
\hline Phosphorous & 6.3 & \\
\hline mg\% & & \\
\hline
\end{tabular}




\section{USES}

\section{- Religious mark:}

Coconut water is considered to be a clean and pure drink. Coconut water has been a religious icon for a long time. Tender coconut water or immature coconut, is provided as ceremonial gifts in India, and it is also used as a purification medium at traditional events ${ }^{3}$.

\section{- Natural beverage:}

Melanesian, Polynesian, and Micronesian mariners used coconut fruits as food and drink reserves many years ago ${ }^{21}$. As a "naturally canned beverage," coconut water is used. Coconut water, obtained from immature nuts, is still drunk as a refreshing drink by thousands of tropical inhibitors today.

\section{- Medicinal use:}

Coconut water has a diversity in applications, perhaps one of the most essential is medicinal ${ }^{7}$. It is defined as "unctuous sweet, increasing semen, promoting digestion, and clearing the urinary path" in Ayurveda medicine ${ }^{3}$. Since coconut has so many medicinal properties, there are numerous references to its medicinal uses in Sri Lanka, where coconut is eaten on an everyday ${ }^{1}$.

Coconut water has long been used to treat burning pain during urination, gastritis, dysuria, burning pain in the eyes, indigestion, and hiccups, as well as the expelling retained placenta. As reported, Coconut water have been used as a short-term intravenous hydration and resuscitation fluid in remote areas of the world and during World War II ${ }^{8-9}$. Sugars dissolve quickly in coconut water ${ }^{10}$, 11. speaking sucrose, sorbitol, glucose, and fructose 12 ${ }^{22}$ are the main sugars found in coconut water, followed by galactose, xylose, and mannose as minor sugars. Aromatic compounds make up a small portion of the body, apart from sugars, minerals, and proteins. Coconut water has a specific taste and flavor which distinctive from that of the coconut kernel. This beverage has a distinct odour that has never been thoroughly described. The taste of coconut water is influenced by organic acids such as malic, succinic, citric, acetic, and tartaric ${ }^{23-24}$, while volatile compounds contribute to the odour of the fresh drink. Coconut water has antioxidant properties 25 , which has interesting curiosity in natural products' nutraceutical properties. Coconut water had the lowest AEAC (L-ascorbic acid equivalent antioxidant capacity): $11.5 \mathrm{mg}$ and $0.7 \mathrm{mg}$ per $100 \mathrm{~g}$ of ascorbic acid. ${ }^{22}$. When compared to coconut water, the coconut kernel has higher values. Coconut water was significantly sweeter, and it caused significantly less nausea, fullness, and stomach upset. Coconut water, unlike carbohydrate-electrolyte beverages and plain water, is often easier to consume in large amounts. A mixture of coconut water and Mauby bark syrup from Trinidad and Tobago that has been shown to reduce hypertension in humans ${ }^{25}$. It also has an impact on blood pressure issues. Coconut water containing L-argentine can have a cardio protective effect due to its production of nitric oxide, which promotes vasorelaxation ${ }^{26}$. Coconut water had nutraceutical effects in menopausal women, reducing histopathological changes in the brain caused by hormonal imbalance ${ }^{27}$. Cococin is a freeze-dried substance that was previously used as the main ingredient in a dietary supplement and an anti-aging skin cream ${ }^{28}$. Coconut water has recently become the subject of medical research since it was used to extract the anticancer properties of cytokinins ${ }^{29-34}$. Kinetin, a cytokinin, also has antithrombotic properties ${ }^{35}$ and the ability to reduce some mammalian species ${ }^{36}$.

\section{CHEMICAL COMPONENTS}

The main composition as phytohormones like auxin, cytokinins; minerals for electrolyte balance like potassium, sodium, magnesium, phosphorus and calcium and other components like vitamins, sugars, etc. The complete composition which delivers nutritional strengths in health \& wealth, as well as in health \& diseases. Phytohormones are essential regulators of plant growth during the development process. Phytohormones are a class of organic compounds found in nature. Auxin, various cytokinins, and gibberellins are present in coconut water 37-40. Other plant growth regulators, including gibberellins (GAS), abscisic acid ( $A B A)$, ethylene, and cytokinins, were later grouped with Auxins as the "Classical five" hormones but preliminary auxin is only classified under phytohormone ${ }^{40}$. Tender coconut water is rich in a number of minerals. Iron, Magnesium, Zinc, Potassium, Phosphorous, and Copper, to name a few. TCW has a high electrolyte content, and its balanced electrolytes, such as sodium and potassium, help to restore electrolyte imbalances through the skin and urinary production ${ }^{41}$

- Auxins: The primary auxin in plants, indole-3-acetic acid (IAA), is contained in coconut water ${ }^{42-43}$. In plants, IAA is a weak acid ( $\mathrm{pKa}=4.75$ ) which synthesized in the meristematic regions at the shoot apex and then transported to the root tip ${ }^{44}$. IAA can be used in its free form as well as conjugated to a variety of amino acids, peptides, and carbohydrates ${ }^{45}$. These biologically inactive IAA conjugates tend to be IAA storage types in plants, and they are possibly involved in hormonal homeostasis ${ }^{46}$. Auxins play a role in relaying environmental signals including light and gravity, controlling branching processes in shoots and roots, and, more recently, patterned cell differentiation in meristems and immature organs ${ }^{47-}$ 48. It is a signal with a wide range of spatial-temporal properties. Auxin transport produces auxin concentration maxima and gradients within tissues, which are essential regulators of embryogenesis, organogenesis, vascular tissue formation, and tropisms, among other plant developmental processes $^{49}$.

- Cytokinins: Natural cytokinins are N6-substituted adenine derivatives with different substituted groups, and their physicochemical activity is affected by side chains, sugar, phosphate, and the degree of purine 
ring and or side chain modification ${ }^{50-52}$. Coconut water contains cytokinins, which are hormones that assist in the growth of plants. Cytokinins are phytohormones or plant hormones that control a plant's growth, development, and ageing. Propagation of several plants, including traditional Chinese medicinal herbs and orchids, is a significant horticultural resource of coconut water. Coconut water contains cytokinins, which aid cell division and encourage rapid development. Cytokinin-treated cells do not go through the usual degenerative process. The richest natural dietary source of cytokines is coconut water. Cytokines have anti-thrombolytic and anti-cancer properties, which can help to reduce the risk of blood clots.

- Vitamins: Coconut water contains these nutrients, which are essential for the normal functioning of the human body. Since fruits and vegetables contain vitamins and minerals essential for normal physiological functions, they are linked to a lower risk of cardiovascular disease, stroke, and cancers of the mouth, pharynx, oesophagus, lungs, stomach, and colon 53-56, 57. Vitamins contained in tender coconut water include Nicotinic acid, Pantothenic acid, Biotin, Riboflavin, Folic acid, and Thiamine. Tender coconut water contains ascorbic acid, which is a water soluble vitamin. Ascorbic acid plays a role in iron absorption, collagen formation, wound healing, immune system function, and cartilage, bone, and tooth maintenance. $41,58,59$ Vitamins B1, B2, B3, B5, B6, B7, and B9 are also found in coconut water. Water-soluble series of vitamin B are needed as coenzymes in enzymatic reactions that are critical for cellular function 60 Vitamin B6 (pyridoxal, pyridoxine, and pyridoxamine) stands as coenzyme which involved in a variety of enzymatic reactions, including transamination and decarboxylation ${ }^{61-66}$. Vitamin B9 is another name for foliate, which is derived from coconut water. Folate protects mitochondria from methanol metaboliteinduced toxicity ${ }^{66}$.

Low levels of vitamin B6 and folate in the blood have been linked to an increased risk of atherosclerosis and other vascular diseases ${ }^{67}$. Vitamin B6 and folate levels in the blood can lower the risk of breast cancer ${ }^{66-67}$. Coconut water contains vitamin $C$, which is an essential dietary antioxidant in addition to vitamin $B$ 66-68. As a result of increased oxidative metabolism, hyper metabolism leads to an increase in reactive oxygen species (or free radicals). The various components of the human cell, especially polyunsaturated fatty acids in the cell membrane and nucleic acids in the nucleus, will be oxidized as a result of the increase in free radicals ${ }^{69}$.

- Sodium: Inside or outside of human cells, the most essential positive ion. Sodium assists in hydrating the body, which is lost via sweat and urine.
- Potassium: Potassium levels in coconut water are significantly higher than in other electrolytes. Hyperkalemia is defined as having too much potassium in the blood, whereas hypokalemia is defined as having too little potassium in the blood. Cation within the cells is referred to as a positive ion. Too much potassium can cause erratic heartbeat, temporary paralysis, and tingling in the hands and feet.

- Magnesium: It aids in the transmission of electrical impulses in body cells, as well as the movement of potassium through muscles for contraction and relaxation. It assists in the production of energy and promotes organ function. A strenuous exercise will deplete magnesium levels, making you vulnerable to cramps, restless muscles, and spasms.

- Phosphorous: It is essential for bone health, as well as transmitting energy across the body, assisting muscle contraction, and controlling nerve function.

- Calcium: It facilitates muscle contraction and function, as well as the transmission of electrical impulses between body cells. Calcium is essential for a variety of reasons, not just healthy bones and teeth. ${ }^{70}$

- Iron: Iron is required for a wide range of cellular functions. The role of iron in hemoglobin production and oxygen transport has been identified as a nutritional benefit. In the human body, it also aids in the conversion of blood sugar into energy. It facilitates oxygen transport and use by cells ${ }^{71}$.

- Sugar: Sugars such as sucrose, glucose, and fructose are present in the endosperm's water. These sugars serve as energy storage units in the human body's metabolism. As compared to other sugars, the element of maturity in coconut is directly proportional to the concentration of sugars, mainly sucrose ${ }^{72}$.

- Copper: Itis one of the metal ions presents in all tissues. It functions as a cofactor for a variety of enzymes and is essential for body function. Copper can help with conditions including Aceruloplasminemia, Alzheimer's disease, and Huntington's disease. Cellular respiration, peptide production, neurotransmitter biosynthesis, and pigment formation are all aided by it ${ }^{73}$.

- Chlorides: Chloride $\left(\mathrm{Cl}^{-}\right)$assists the body in maintaining a normal fluid balance. The ion chloride is important for human health. It is combined with hydrogen ions to form $\mathrm{HCl}$, a stomach acid that is essential for the body's gastrointestinal tract. Chloride $\left(\mathrm{Cl}^{-}\right)$and bicarbonate $\left(\mathrm{HCO}_{3}{ }^{-}\right)$ions keep blood $\mathrm{pH}$ stable. It also aids in the maintenance of blood volume and pressure ${ }^{74}$.

- Amino acids: Amino acids are essential for tissue repair. The amino acids alanine, arginine, cysteine, and serine are more abundant in coconut water. It's a 
good source of arginine, which aids the body's stress response. Arginine can also aid in the maintenance of a healthy heart.Tender coconut water contains trace quantities of amino acids including aspartic acid, glutamic acid, histidine, leucine, lysine, proline, phenylalanine, and tyrosine. Amino acids are a group of organic compounds that make up proteins' building blocks. They play a role in nearly every bodily function, including growth and development, normal digestion, and energy production. Some can also help with sleep and muscle loss. Amino acids have been shown to boost mood and aid weight loss $41,58,71,73-74$.

\section{ADVANCE RESEARCH OPPORTUNITIES}

Coconut water has a variety of health benefits, including hydrating the body and strengthening the immune system. According to clinical research, the presence of lauric corrosive makes it difficult to comprehend the benefits of consuming virgin coconut oil (VCO) and the recommended intake amounts.

\section{- Lead for diabetic patients:}

Coconut water has been shown to lower glucose levels and increase other well-being indicators in diabetic patients ${ }^{75}$. Diabetic patients treated with coconut water maintained better glucose levels than the control group; coconut water also had lower haemoglobin A1C levels, showing excellent long-term glucose control and improvements in glucose levels and oxidative pressure creators ${ }^{76-80}$.

\section{- Anti-bacterial property:}

Coconut water's antibacterial properties, the inclusion of lauric acid, and the ability to extract antimicrobial peptides Cn-AMP 75, 77, 81 from delicate coconut water have all drawn attention to its suitability for everyday use. An in-vitro study was conducted to determine the antimicrobial viability of delicate coconut water in its natural state against Streptococcus mutants ${ }^{81}$.With the delicate coconut water, which was fresh and sterile, and negative control (dimethyl formamide), there was no zone of restraint ${ }^{78}$. Sure monitoring $(0.2 \%)$ chlorhexidine trace tests of thiamine B1 and pyridoxine B6 showed a zone of restraint. Coconut water also includes calories, sugar liquor, vitamin C, folic acid, free amino acids, phytohormones, chemicals, and growth factors. Coconut water is clean in its envelope and contains both organic and inorganic ingredients (practically all minerals found in food). Coconut water was screened to identify defense peptides with bactericidal properties ${ }^{77}$, as it is regarded as a popular medicine in various human advancements. Nucifera has long been regarded as a component with a variety of uses associated with each segment, as well as being naturally dynamic in some way ${ }^{82}$. Leishmaniosis wounds are treated with a C. nucifera concentrate. It is used as a rehydrating agent in cholera, loose bowels, and diarrhoea, cancer treatment, and as a hair supplement in alopecia in the Indian subcontinent. The roots are astringent, diuretic, and anthelmintic, and can be used to treat pharyngodynia, uterine problems, blennorrhagia, bronchitis, hepatitis, strangury, and helminthiasis 79, 81, 83 Coconut water is thought to aid with urinary infections, kidney stones, and sexual vigour.The harmful to microbial robotic operation of coconut oil actuates the soothing concept of the resistant reaction in the human body, as the government has emphasised the Ayurveda company to focus in on products to repair Coronavirus. The study referenced that coconut oil as a wellbeing oil was viewed in Ayurveda medication just about 4000 years prior $80,83,84$

\section{- Effective for kidney stone:}

Kidney stone prevention necessitates adequate hydration. Despite the fact that plain water is an unthinkable choice, one study suggests that coconut water may be even better. Kidney stones form when calcium, oxalate, and other compounds combine to form gems which will able to give shape as stone ${ }^{85-87}$. However, some gatherings are avoided to producing stone when coconut water intake is more ${ }^{88}$.

\section{REFERENCES}

1. Ediriweera E.R.H.S.S, Medicinal uses of coconut (Cocosnucifera L.), Cocoinfolnt, 2003;10:11-21.

2. Osazuwa O.E, Ahonkhai I, Coconut water as growth medium for micro-organisms, Niger. J. Palms Oil Seeds, 1989;10 (11):91-95.

3. Rethinam P, Kumar T.B.N, Tender coconut -an overview, Indian Coconut J, 2001;32:2-22.

4. Sanchez P.C, Collado L.S, GerpacioC.L, Lapitan H, Village level technology of processing coconut water vinegar, Philipp.Agric, 1985;07:439-448.

5. Augustine S.P, Wine produced using tender coconut and product, Patent US2007/ 017897 A1, Inde, 2007.

6. Saat $M$, Singh $R$, GaminiSirisinghe $R$, Nawawi $M$, Rehydration after exercise with fresh young coconut water, carbohydrate electrolyte beverageand plain water, J. Physiol, Anthropol. Appl. Hum.Sci, 2002; 21:93-104.

7. Nanda Kumar T.B, Tender coconut water: nature's finest drink, Indian Coconut J, 1990; 21:14-18.

8. Campbell-Falck D, Thomas T, FalckT.M, Tutuo N, Clem K, The intravenous use of coconut water, Am. J. Emerg. Med, 2000; 18:108-111. doi: 10.1016/s0735-6757(00)90062-7

9. Pummer S, Heil P, Maleck W, Petroianu G, Influence of coconut water on hemostasis, Am. J. Emerg. Med, 2001; 19:287-289. doi: 10.1053/ajem.2001.24477.

10. Lapitan O.B, Mabesa R.C, Chemical and sensory characteristics of Laguna and Golden coconuts (Cocosnucifera L.), Philipp.Agric, 1983; 66:144-150.

11. Pue A.G, Rivu W, Sundarrao C, Singh K, Preliminary studies on changes in coconut water during maturation of the fruit, Sci. New Guin, 1992; 18:81-84.

12. Del Rosario J.E, Bergonia H.A, Flavier M.E, Samonte J.L, Mendoza E.M.T, Chromatographic analysis of carbohydrates in coconut water, Trans. the Natl. Acad. Sci.Technol, 1984; 6:127-151. Doi: https://doi.org/10.1051/fruits/2012002 
13. Matsui, K. N., Granado, L. M., de Oliveira, P. V., \&Tadini, C. C. Peroxidase and polyphenol oxidase thermal inactivation by microwaves in green coconut water simulated solutions. LWT - Food Science and Technology, 2007;40(5):852-859. doi:10.1016/j.Iwt.2006.03.019

14. P. Evans, B. Halliwell, Micronutrients: Oxidant/antioxidant Status. Br. J. Nutr. 2001;85:67-74. PMID: 11509092

15. Institute of medicine (IOM), Dietary Reference intakes for calcium phosphorous, magnesium, Vitamin, and fluoride, National Academy Prem; Washington DC, USA, 2000. doi: 10.17226/5776; PMID: 23115811.

16. Vigliar R, Sdepanian V.L, FagundesNeto U, Biochemical profile of coconut water from coconut palms planted in an inland region, J Pediatr (Rio J), 2006; 82:308-312. DOI: 10.2223/JPED.1508; PMID: 1691283

17. Santoso U, Kubo, K, Ota T, Tadokoro T, Maekawa A, Nutrient composition of kopyor coconuts (Cocosnucifera L.), Food Chem, 1996;57:299-304. doi: https://doi.org/10.1016/0308-8146(95)00237-5.

18. Markose V.T, Sree Kumar Poduval, Processing and value addition of coconut, Coconut Development Board, India, 2009;3.

19. Jackson, J.C, Gordon A, Wizard, G, Mc Cook K, Rolle R, Changes in chemical composition of coconut (cocosnucifera $\mathrm{L}$ ) water during maturation of the fruit, J. Sci food Agric; 2004;54:1049 - 1052. https://doi.org/10.1002/isfa.1783.

20. Reddy, P., Lakshmi M, Coconut water properties, uses, and nutritional benefits in health and disease review, Journal of current clinical medicine and laboratory biochemistry, 2003;10(2):11-21.

21. Bourdeix R, Konan J.L, N'Cho Y.P, Coconut: A guide to traditional and improved varieties, Ed. Diversiflora, Montpellier, France, Editions Diversiflora, 2005;104.

22. Unagul $P$, Assantachai $C$, Phadungruengluij $S$, Ogundiya M.O, Glucose content of nut water in four varieties of coconut palm (Cocosnucifera), J. Sci. Food Agric, 1991;56:399-402.

23. Suphantharika M, Tanticharoen M, Verduyn C, Coconut water as a medium additive for the production of docosahexaenoic acid (C22:6 n3) by Schizochytriummangrovei Sk-02, Bioresour. Technol, 2007; 98:281-287. PMID: 16563749.

24. Santoso U, Kubo K, Ota T, Tadokoro T, Maekawa A, Nutrient composition of kopyor coconuts (Cocosnucifera L.), Food Chem, 1996;57:299-304. doi: https://doi.org/10.1016/0308-8146(95)00237-5.

25. Alleyne $T$, Roache $S$, Thomas $C$, Shirley $A$, The control of hypertension by use of coconut water and mauby: two tropical food drinks, West Indian Med. J, 2005;54:3-8. doi: 10.1590/s0043-31442005000100002. PMID: 15892382.

26. Anurag P, Sandhya V, G, Rajamohan T, Cardioprotective effect of tender coconut water, Indian Coconut J. 2007; 37:22-25.

27. K.Rundorn W, Withyachumnarnkul B, Connor J.R., Young coconut juice significantly reduces histopathological changes in the brain that is induced by hormonal imbalance:a possible implication to postmenopausal women, Histol. Histopathol, 2009; 24:667674.doi: 10.14670/HH-24.667. PMID: 19337965.

28. Prakash $\mathrm{L}$, Natural ingredients nurture skin health from the inside and out, NutraCos, 2008; 7:6-9.

29. Ge L, Peh C.Y.C, Yong J.W.H, Tan S.N.,Hua L, Ong E.S, Analyses of gibberellins by capillary electrophoresis-mass spectrometry combined with solid-phase extraction, J. Chromatogr. A, 2007; 1159:242-249. doi: 10.1016/i.chroma.2007.05.041. PMID: 17543977.

30. Ge L, Yong W.H, Tan S.N, Yang X.H, Ong E.S, Analysis of some cytokinins in coconut (Cocosnucifera L.) water by micellarelectrokinetic capillary chromatography after solidphase extraction, J. Chromatogr. A, 2004; 1048:119126. doi: 10.1016/j.chroma.2004.07.031.

31. Ge L, Yong J.W.H, Goh N.K, Chia L.S, Tan S.N, Ong E.S, Identification of kinetin and kinetin riboside in coconut (Cocosnucifera L.) water using a combined approach of liquid chromatography-tandem mass spectrometry, high performance liquid chromatography and capillary electrophoresis, J. Chromatogr. B, 2005; 829:26-34. doi: 10.1016/j.jchromb.2005.09.026.

32. Ge L, Yong J.W.H, Tan S.N., Hua L, Ong E.S, Analyses of gibberellins in coconut (Cocosnucifera L.) water by partial filling micellarelectrokinetic chromatography mass spectrometry with reversal of electro osmotic flow, Electrophoresis, 2008;29:2126-2134. doi: $10.1002 /$ elps.200700717.

33. Ge L, Yong J.W.H, Tan S.N, Ong E.S, Determination of cytokinins in coconut (Cocosnucifera L.) water using capillary zone electrophoresis-tandem mass spectrometry, Electrophoresis, 2006;27:2171-2181. doi: $10.1002 /$ elps.200500465.

34. Ge L, Yong J.W.H, Tan S.N, Yang X.H, Ong E.S, Analysis of cytokinin nucleotides in coconut (Cocosnucifera L.) water using capillary zone electrophoresis-tandem mass spectrometry after solid-phase extraction, J. Chromatogr. A, 2006; 1133: 322331.doi: 10.1016/i.chroma.2006.08.027.

35. Hsiao G, Shen M.-Y, Lin K.-H, Chou C.-Y, Tzu N.-H, Lin C.-H, Chou D.-S, Chen T.-F, Sheu J. R, Inhibitory activity of kinetin on free radical formation of activated platelets in vitro and on thrombus formation in vivo, Eur. J. Pharmacol,2003;465: 281-287. doi: 10.1104/pp.900083.

36. Vermeulen K, Strnad M, Krytof V, Havlíck L, Van der Aa A, Lenjou M, Nijs G, Rodrigus I, Stockman B, van Onckelen H, Van Bockstaele D.R, Berneman Z.N, Antiproliferative effect of plant cytokinin analogues with an inhibitory activity on cyclindependent kinases, Leukemia 2002;16:299305.doi: 10.1038/sj.leu.2402378.

37. Matsui KN, Gut JAW, de Oliveira PV, Tadini C.C, Inactivation kinetics of polyphenoloxidase and peroxidase in green coconut water by microwave processing. Journal of Food Engineering, 2008; 88:169-176. doi: 10.1016/j.jfoodeng.2008.02.003.

38. Fonseca AM, Monte FJQ, da Conceic M, de Oliveiraaão F, Coconut water (Cocosnucifera L.) - A new biocatalyst 
system for organic synthesis, Journal of Molecular Catalysis B: Enzymatic. 2009; 57:78-82.

39. Mandal SM, Dey S, Mandal M, Sarkar S, Maria-Neto S, Franco OL, Identification and structural insights of three novel antimicrobial peptides isolated from green coconut water, Peptides, 2009;30:633-637.

40. Kende H, Zeevaart. J, The five "Classical" plant hormones, Plant Cell, 2018;9: 1197-1210.

41. Jean Yong W.H, LiyaGe, Yan Fei Ng and SweeNgin Tan, The Chemical Composition and Biological Properties of Coconut (Cocosnucifera L.) Water, Molecules, 2009;14:5144-5164.

42. Ma Z, Ge L, Lee A.S.Y, Yong J.W.H, Tan, S.N, Ong E.S, Simultaneous analysis of different classes of phytohormones in coconut (Cocosnucifera L.) water using high-performance liquid chromatography and liquid chromatography- tandem mass spectrometry after solidphase extraction, Anal. Chim. Acta, 2008; 610:274-281.

43. $\mathrm{Wu} \mathrm{Y,} \mathrm{Hu} \mathrm{B,} \mathrm{Simultaneous} \mathrm{determination} \mathrm{of} \mathrm{several}$ phytohormones in natural coconut juice by hollow fiberbased liquid-liquid-liquid microextraction-high performance liquid chromatography, J. Chromatogr. A, 2009; 1216:7657-7663.

44. Blakeslee J.J, Peer W.A, Murphy A.S, Auxin transport. Curr. Opin. Plant Bio, 2005; 8:494-500. doi:10.1016/j.pbi.2005.07.014.

45. Bialek L, Michalczuk L, Cohen J.D, Auxin biosynthesis during seed germination in Phaseolus vulgaris, Plant Physiol, 1992;100:509-517. doi:10.1104/pp.100.1.509.

46. Jakubowska A, Kowalczyk S.A, specific enzyme hydrolyzing 6-O(4-O)-indole-3-ylacetyl- $\beta$-d glucose in immature kernels of Zea mays, J. Plant Physiol, 2005;162:207-213. doi:10.1016/j.jplph.2004.05.015.

47. Berleth T, Krogan N.T, Scarpella, E, Auxin signals - turning genes on and turning cells around, Curr. Opin. Plant Bio, 2004; 7:553-563. doi:10,1016/j.pbi.2004.07.016.

48. Dharmasiri N, Dharmasiri S, Weijers D, Lechner E, Yamada M, Hobbie L, Ehrismann J.S, Jurgens G, Estelle M, Plant development is regulated by a family of auxin receptor $F$ Box proteins, Dev.Cell, 2005;9:109-119. doi:10.1016/j.devcel.2005.05.014.

49. Robert H.S, Friml J, Auxin and othersignals on the move in plants, Nat. Chem. Biol, 2009;5:325-332. doi:10.1038/nchembio.170.

50. Miller C.O, Skoog F, Von Saltza M.H, Strong F.M, Kinetin a cell division factor from deoxyribonucleic acid, J. Am. Chem. Soc, 1995; 77:1392-1393. doi:http//doi.org/10.1021/ja01610a105.

51. Werner T, Motyka V, Strnad M, Schmulling T, Regulation of plant growth by cytokinin, Proc. Natl. Acad. Sci. USA, 2001;98:10487-10492. doi:10.1073/pnas.171304098.

52. Amasino R.M, Kinetin arrives, the $50^{\text {th }}$ anniversary of a new plant hormone, Plant Physiol, 2005; 138:1177-1184.

53. Gillman M.W, Cupples L. A, Gagnon D, Posner B.M, Ellison R.C, Castelli W.P, Wolf P.A, Protective effect of fruits and vegetables on development of stroke in men, J. Am. Med. Assoc, 1995;273:1113-1117.
54. Joshipura K.J, Hu F.B, Manson J.E, Stampfer M.J, Rimm E.B, Speizer F.E, Colditz G, Ascherio A, Rosner B, Spiegelman D, Willett W.C, The effect of fruit and vegetable intake on risk for coronary heart disease, Ann. Intern. Med, 2001; 134:1106-1114. Doi: 10.7326/0003-4819-134-12200106190-00010.

55. Bazzano, L.A, He, J, Ogden, L.G, Loria, C.M, Vupputuri, S, Myers, L, Whelton, P.K , Fruit and vegetable intake and risk of cardiovascular disease in US adults: The first national health and nutrition examination survey epidemiologic follow-up study. Am. J. Clin. Nutr, 2002; 76: 9399.doi:10.1093/ajcn/76.1.93.

56. Riboli E, Norat T, Epidemiologic evidence of the protective effect of fruit and vegetables on cancer risk, Am. J. Clin. Nutr, 2003; 78:559-569. doi:10.1093/ajcn/78.3.559S.

57. Tucker G.A, Roberts J.A, Plant Hormone Protocols, Humana Press Inc.: Totowa, NJ, USA, 2000; 200.

58. Ewan H, Michael B, Zemelb, Functional properties of whey, whey components, and essential amino acids: mechanisms underlying health benefits for active people (review), The Journal of Nutritional Biochemistry, 2003; 14:251-258.

59. Edward B, Martin P, Christine E, SeidmanSeidman J. G, YaHuei Wu Chou, Calcium-lon-Sensing Cell-Surface Receptors, The New England Journal of medicine, 1995;333:234-240.

60. Depeint F, Bruce W.R, Shangari N, Mehta R, O'Brien P.J, Mitochondrial function and toxicity: Role of $B$ vitamins on the one-carbon transfer pathways, Chem. Biol. Interact, 2006;163:113-132. doi:10.10016/j.cbi.2006.05,010.

61. Garrett R.H, Grisham G.M, Biochemistry, 3rd ed.; Thomson Brooks/Cole: Belmont, CA, USA, 2005.

62. Matsuo Y, Greenberg D.M, A crystalline enzyme that cleaves homoserine and cystathionine: III, Coenzyme resolution, activators, and inhibitors, J. Biol. Chem, 1958; 234:507-515.

63. Carroll W.R, Stacy G.W, du Vigneaud V, $\alpha$-Ketobutyric acid as a product in the enzymatic cleavage of cystathionine, J. Biol. Chem, 1949;180:375-382.

64. Conn E.E, Stumpf P.K, Outlines of Biochemistry, John Wiley \& Sons, Inc. New York, NY, USA, 1972; 3:436-437.

65. Lieberman M, Marks A.D, Smith C, Mark's Essentials of Medical Biochemistry, A Clinical Approach, Lippincott Williams \& Wilkins, Baltimore, MD, USA, 2007.

66. Shenkin $A$, The key role of micronutrients, Clinical Nutr, 2006; 25:1-13. doi:10.1016/j.clnu.2005.11.006.

67. Robinson K, Arheart K, Refsum H, Brattström L, Boers G, Ueland P, Rubba P, Palma-Reis R, Meleady R, Daly L, Witteman J, Graham I, Low circulating folate and vitamin B6 concentrations: Risk factors for stroke, peripheral vascular disease and coronary artery disease, Circulation, 1998;97:437-443. doi:10.1161/01.cir.97.5.437.

68. Rattan S.I.S, Method and composition for ameliorating the adverse effects of aging, US Pat, 1994; 537108.

69. Evans $P$, Halliwell $B$, Micronutrients: Oxidant/antioxidant Status. Br, J. Nutr, 2001; 85:S67-S749. doi:10.1001/jama.1995.03520380049034. 
70. E prabhakar Reddy, T.Mohana Lakshmi. Coconut Water Properties, Uses, Nutritional Benefits in Health and Wealth and in Health and Disease: A Review. April- June 2014; Volume 2 Issue 2: Page 12.

71. Nancy C. Andrews, Iron metabolism: Iron Deficiency and Iron Overload, Genomics and Human Genetics, 2000; 1:7598. doi:10.1146/annurev.genom.1.1.75.

72. Ogundiya M.O, Glucose content of nut water in four varieties of coconut palm (Cocos nucifera), J. Sci. Food Agric, 1991; 56:399-402. doi:https://doi.org/10.1002/jsfa.2740560315.

73. Desai V, Stephen $G$ Kaler, Role of copper in human neurological disorders", Am J ClinNutr, 2008; 88:855-858. doi: https://doi.org/10.1093/ajcn/88.3.855S.

74. Franz J, "Gastric Function”, Nutrition Today, 1971; 6:2-11.

75. Joseph R. R, Vincent H L Lee, Controlled Drug Delivery, Marcel Dekker, Inc. New York, 1987;29(2):42-43.

76. Edith Mathiowitz, Donald E. C, Claus - Michael L, Bioadhesive Drug Delivery Systems -Fundamentals, Novel Approaches and Development, Marcel Dekker, Inc., New York,1999;98(2):541-562.

77. Jain N. K, "Controlled and Novel Drug Delivery", $1^{\text {st }}$ Edition, CBS Publishers and Distributors, India, 2004; 52-74.

78. Amir H Shojaei, Buccal mucosa as a route for systemic drug delivery, J.Pharm. Pharmaceut. Sci, June, 1998; 15:15-30.
79. Swarbrick J, Boylan C, James, Encyclopedia of Pharmaceutical Technology, Marcel Dekker, Inc., New York, 1990; 2(2):189-210.

80. Yie W, Chein, Novel Drug Delivery Systems, Marcel Dekker, Inc., New york, 1992; vol.50 (2):8-9,197-228,456-457.

81. Michael J. Rathbone, Oral Mucosal Drug Delivery, Drug and Pharmaceutical sciences, Marcel Dekker Inc, New York, 1992;2(2):18-24.

82. Verma R. K, Krishna D. M, Garg S, Formulation aspects in the development of osmotically controlled oral drug delivery systems, J controlled release, 2002;(79):7-27.

83. James S, James C. B, Encyclopedia of Pharmaceutical Technology, Marcel Dekker, Inc., New York, 1990; 10(3):133.

84. Robinson J. R, Sustained and controlled release drug delivery, Marcel Dekker, New York, 1987; 72-76.

85. Robert S L, Donald L. W, MedicalApplications of Controlled Release, 1984; 42.

86. Bhosle A. V, Tukawalw R. V, Sawant S.D, Oral Novel Drug Delivery System The Eastern Pharmacist, 2002;41-43.

87. Aulton M.E, Pharmaceutics the Science of dosage form design, Churchill living stone, 2002; 2:41-43.

88. Robinson J.R, Lee V. H, Controlled drug delivery, Marcel dekker, 1987;2:376-391.

Source of Support: The author(s) received no financial support for the research, authorship, and/or publication of this article.

Conflict of Interest: The author(s) declared no potential conflicts of interest with respect to the research, authorship, and/or publication of this article.

For any question relates to this article, please reach us at: editor@globalresearchonline.net New manuscripts for publication can be submitted at: submit@globalresearchonline.net and submit_ijpsrr@rediffmail.com 